\section{Abdominal obesity in Japanese-Brazilians: which measure is best for predicting all-cause and cardiovascular mortality?}

\author{
Obesidade abdominal em nipo-brasileiros: que \\ medida antropométrica tem maior capacidade \\ de predizer a mortalidade geral e por \\ doenças cardiovasculares?
}

\author{
${ }^{1}$ Departamento de Medicina \\ Preventiva, Universidade \\ Federal de São Paulo, São \\ Paulo, Brasil. \\ Correspondence \\ M. R. Bevilacqua \\ Departamento de Medicina \\ Preventiva, Universidade \\ Federal de São Paulo. \\ Rua Vigário Albernaz 843, \\ apto. 24, São Paulo, SP \\ 04134-021, Brasil. \\ marsellerb@yahoo.com.br
}

\begin{abstract}
This study aimed to verify which anthropometric measure of abdominal obesity was the best predictor of all-cause and cardiovascular mortality in Japanese-Brazilians. The study followed 1,581 subjects for 14 years. Socio-demographic, lifestyle, metabolic, and anthropometric data were collected. The dependent variable was vital status (alive or dead) at the end of the study, and the independent variable was presence of abdominal obesity according to different baseline measures. The mortality rate was estimated, and Poisson regression was used to obtain mortality rate ratios with abdominal obesity, adjusted simultaneously for the other variables. The mortality rate was 10.68/thousand person-years. Male gender, age $\geq 60$ years, and arterial hypertension were independent risk factors for mortality. The results indicate that prevalence of abdominal obesity was high among Japanese-Brazilians, and that waist/hip ratio was the measure with the greatest capacity to predict mortality (especially cardiovascular mortality) in this group.
\end{abstract}

Anthropometry; Abdominal Obesity; Mortality
Marselle Rodrigues Bevilacqua 1 Suely Godoy Agostinho Gimeno 1

\section{Introduction}

In developed and developing countries, obesity has become the fastest-growing nutritional and public health problem in recent years 1 . In the United States in 2003-2004, 66.3\% of Americans had some degree of excess weight 2 . In Japan, data from the National Nutrition Survey showed that the prevalence rates for overweight and obesity among individuals 20 years or older were $24.5 \%$ and $2.3 \%$, and $17.8 \%$ and $3.4 \%$, for males and females, respectively ${ }^{3}$. In Brazil, the results of the Family Budget Survey (POF 2008-2009) indicated that $50.1 \%$ of men and $48 \%$ of women were overweight, and that obesity prevalence was $12.4 \%$ in males and $16.9 \%$ in females 4 .

Given this new scenario, characterized by high prevalence of obesity, cardiovascular diseases appear as the leading public problem and diseases of the circulatory system are the principal cause of deaths in Brazil as a whole (32\%) and in all its geographic regions (Rede Interagencial de Informações para a Saúde. Indicadores de Mortalidade. http:/ / tabnet.datasus.gov.br/cgi/ deftohtm.exe?idb2009/c04.def).

Epidemiological studies have used body mass index (BMI) on a large scale to assess excess weight, but it is currently known that abdominal fat is more closely associated with increased risk of morbidity and mortality from cardiovascular disease and metabolic disorders such as dyslipidemia, hypertension, and diabetes mellitus 5,6. 
Regional obesity measures, including waist circumference (WC), waist/hip ratio, and waist/ height ratio provide estimates of central adiposity, which in turn is related to the amount of visceral adipose tissue ${ }^{6}$.

Despite the superiority of regional measures of body fat distribution over BMI, the results of different studies are inconclusive as to which anthropometric measure or indicator is best for predicting cardiovascular events and mortality. Some authors defend the use of waist/hip ratio to identify subjects at greatest risk of ischemic heart disease 7 and all-cause and cardiovascular mortality ${ }^{8}$. Others show the superiority of WC associated (or not) with BMI for predicting all-cause and cardiovascular mortality ${ }^{9}$. Various studies of Japanese individuals have indicated that waist/ height ratio corresponds more closely to metabolic risk in subjects with and without generalized obesity 10,11,12.

Some ethnic groups have higher prevalence rates for excess weight. Studies of migrants have shown that the increase in body weight is associated with the variables involved in the process of adapting to the new environment, such as socio-cultural stress, altered diet patterns, and reduction in physical activity 13. For example, both in Brazil and the United States, Japanese emigrants when compared to individuals that remained in Japan show higher susceptibility to both increased body weight and accumulation of adipose tissue in the abdominal region, thus worsening their insulin sensitivity 14,15,16.

Therefore, the principal aim of the current study was to verify which measure used in the identification of abdominal obesity best predicts all-cause and cardiovascular mortality among Japanese-Brazilians, independently of the presence of generalized obesity.

\section{Materials and methods}

Data were used from the cohort study conducted by the Japanese-Brazilian Diabetes Study Group (JBDSG) among the Japanese-Brazilian community in Bauru, São Paulo State, Brazil. The study was conducted with first-generation Japanese immigrants (Issei, born in Japan) and secondgeneration (Nisei, born in Brazil and children of the first generation), of both genders, ages $\geq$ 30 years. These individuals were examined three times (1993, 2000, and 2005-2007), using a methodology described elsewhere 13,14,15,16,17.

Briefly, in 1993, after a local census performed by the JBDSG, 1,518 Japanese-Brazilians were identified ranging in age from 40 to 79 years, of whom 1,137 were first- or second-generation
(293 Issei and 764 Nisei). A systematic sample of 706 individuals was selected (all the Issei and one-third of the Nisei, with an additional $20 \%$ to compensate for possible losses) and 647 individuals participated in the study $(91.6 \%$ of the selected individuals). In 1999-2000, after a new census in the community, 1,751 first- and secondgeneration individuals $\geq 30$ years of age living in Bauru were identified; 1,330 individuals participated (76\% of the total population), of whom 394 had also been examined in 1993. Among those that did not participate in the study, there was a higher proportion of males and individuals $\leq$ 60 years of age, as compared to participants. The third phase of the research took place in 20052007 and involved a community intervention study on lifestyle (diet and physical activity). All the participants were invited to participate in the second phase of the survey (1999-2000), along with their family members; a total of 736 individuals were evaluated (55.3\%). Reasons for nonparticipation included death $(n=101)$, change of address, or refusal ( $n=493$; Figure 1$)$.

For the current study, complete information was available on the presence or absence of baseline abdominal obesity and vital status at the end of the study (alive or dead) for 1,581 JapaneseBrazilians (98.9\% of those eligible); of these, 1,411 subjects were alive at the end of the study. Of the 170 deaths recorded during the study period (1993 to 2007), it was possible to identify the date and cause of death (based on a death certificate) in 154 cases $(90.6 \%)$. Classification of cause of death used the 10th Revision of the International Classification of Diseases (ICD-10).

All the participants signed the informed consent form in the three study phases, and the study project was approved by the Institutional Review Board of the Federal University in São Paulo (UNIFESP), under case file 1907/06.

Similar research protocols were used in 1993 and $200013,14,15,16,17$. Initially, subjects were informed of the study objectives by telephone (or in person). After agreeing to participate, two home visits were scheduled to apply the sociodemographic and food survey questionnaires. On the day of the home interview, the interviewer scheduled the date for the physical examination and collection of laboratory samples. The sociodemographic questionnaire was used to obtain baseline information on gender (female versus male), age ( $<60$ years versus $\geq 60$ years), generation (first versus second), schooling (in Brazil and Japan, $<4$ years of study versus $\geq 4$ years), marital status (single/widowed/divorced versus married), smoking (none versus current or past), alcohol consumption (none versus current or past), history of illness (no/yes), working status 
Number of Japanese-Brazilians examined or lost to follow-up in the three phases of the Japanese-Brazilian Diabetes Study Group cohort. Bauru, São Paulo State, Brazil, 2007.

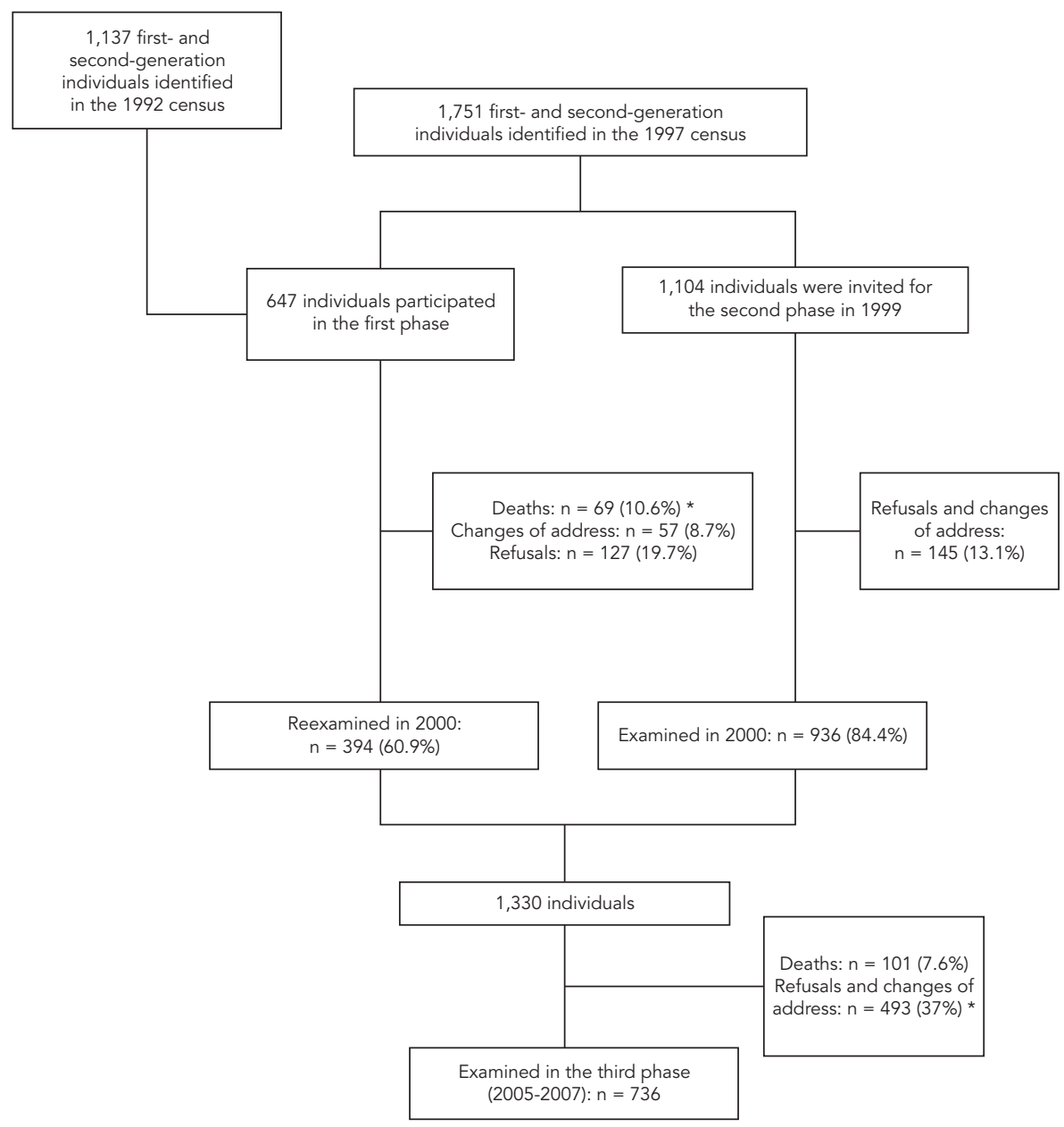

* Deaths from 1993 to $2007: 69+101=170$.

(no/yes), and regular physical activity (sedentary/light versus moderate/intense).

On the day of the medical examination, in addition to the clinical and laboratory procedures, subjects answered a questionnaire on their personal health and use of medications. All subjects underwent a physical examination (including anthropometry and blood pressure) and laboratory tests (blood glucose and lipid profile, among others). The clinical examination was performed by physicians from the Department of Preventive Medicine, UNIFESP.

Body weight was measured in kilograms on a platform type scale (Filizola, São Paulo, Brazil) with a capacity of $200 \mathrm{~kg}$, accurate to $100 \mathrm{~g}$, placed on a flat surface and calibrated for each weighing. Height was measured with a manual stadiometer attached to the wall, with a maximum height of $2 \mathrm{~m}$, accurate to $1 \mathrm{~cm}$ (Sanny, São Paulo, Brazil). The study used World Health Organization (WHO) 18 guidelines for classifying individuals by nutritional status according to BMI [weight in $\mathrm{kg}$ / (height in meters)2].

WC was measured with a non-stretchable tape measure at the level of the umbilicus, rounded to the nearest $0.1 \mathrm{~cm}$. This measurement was taken with the subject standing erect, abdomen relaxed, arms hanging by the side, and 
feet together. Abdominal obesity was defined as WC $\geq 80 \mathrm{~cm}$ and $\geq 90 \mathrm{~cm}$ for women and men, respectively, which are specific values for the Japanese-descendent population 19,20. Hip circumference was measured at the level of the greater femoral trochanters, around the most prominent area of the buttocks, with the tape measure held horizontally. Abdominal obesity, as assessed by waist/hip ratios, was defined as $\geq 0.95$ for men and $\geq 0.80$ for women 21 .

Waist/height ratio was calculated as the ratio between WC $(\mathrm{cm})$ and stature $(\mathrm{cm})$. Abdominal obesity was defined in both genders as waist/ height ratio $\geq 0.510,11$.

An automatic blood pressure monitor (HEM712C automatic digital device with a cuff adjusted to the brachial circumference; Omron Health Care, USA) was used to measure systolic (SBP) and diastolic blood pressure (DBP). After resting for 10 minutes, three SBP and DBP measurements were taken, and the final value was defined as the mean of the latter two. Hypertension was defined as SBP $\geq 140 \mathrm{mmHg}$ or DBP $\geq$ $90 \mathrm{mmHg}$ or regular use of medication for hypertension 22 .

Two blood samples were taken (fasting and two hours after a $75 \mathrm{~g}$ oral glucose challenge). Glucose intolerance was defined according to WHO guidelines: normal (fasting blood glucose $<110 \mathrm{mg} / \mathrm{dL}$ and 2-hour glucose < 140mg/dL), impaired fasting glucose - IFG (fasting glucose $\geq 110 \mathrm{mg} / \mathrm{dL}$ and $<126 \mathrm{mg} / \mathrm{dL}$ and two-hour glucose $<140 \mathrm{mg} / \mathrm{Dl}$ ), impaired glucose tolerance IGT (fasting glucose $<126 \mathrm{mg} / \mathrm{dL}$ and 2-hour glucose $\geq 140 \mathrm{mg} / \mathrm{dL}$ and $<200 \mathrm{mg} / \mathrm{dL}$ ), and diabetes (fasting glucose $>126 \mathrm{mg} / \mathrm{dL}$ or 2 -hour glucose $>200 \mathrm{mg} / \mathrm{dL}) 23$.

Serum lipids were measured using enzymatic methods. Dyslipidemia was defined as total cholesterol $>200 \mathrm{mg} / \mathrm{dL}$ or triglycerides $>150 \mathrm{mg} / \mathrm{dL}$ or $\mathrm{HDL}<40 \mathrm{mg} / \mathrm{dL}$ in males and $<50 \mathrm{mg} / \mathrm{dL}$ in females or LDL > 130mg/dL 24.

\section{Statistical data analysis}

The dependent (outcome) variable was defined as status at the end of the study (alive versus allcause death or alive versus cardiovascular death). The independent or target variable was presence of abdominal obesity according to each of the three different anthropometric measures (WC, waist/hip ratio, and waist/height ratio).

Control variables included gender (male versus female), age ( $<60$ years versus $\geq 60$ years), generation (second versus first), schooling in Brazil ( $\leq 4$ years and $>4$ years), marital status (single/ widowed/divorced versus married), BMI (underweight, normal, overweight, or obese), presence of dyslipidemia (yes/no), glucose tolerance (normal, IFG, IGT), presence of hypertension (yes/ no), smoking (current or past yes versus no), and regular alcohol consumption (yes/no).

Crude analysis provided mean and point values and 95\% confidence intervals (95\%CI) for continuous variables. The Student t test was used to verify the existence of differences between the means for socio-demographic, nutritional, and metabolic variables according to status at the end of the study (alive versus all-cause mortality or cardiovascular mortality). Mean and point all-cause and cardiovascular mortality rates and 95\%CI were calculated. The chi-square test and mortality rates ratios were used to identify associations between mortality and presence of abdominal obesity (according to WC, waist/hip ratio, and waist/height ratio), as well as the other categorical control variables.

Poisson multiple regression was used to obtain ratios between mortality rates and presence of abdominal obesity according to the different criteria, adjusted for the control variables. Four models were constructed for each anthropometric measure, namely: (a) model 1: adjusted only for gender and age; (b) model 2: variables from model 1 plus generation, working status, schooling, and marital status; (c) model 3: variables included in model 2 plus physical activity, alcohol consumption, and smoking; and (d) model 4: variables included in model 3 plus BMI, glucose tolerance, dyslipidemia, and hypertension.

Statistical analysis used Stata, version 10.0 (Stata Corp., College Station, USA).

\section{Results}

Mean age of participants upon entering the cohort was 55.63 years (standard deviation $-\mathrm{SD}=$ 11.80 years), and $61.3 \%(n=960)$ were under 60 years. Of the total $(n=1,565), 22.8 \%(n=357)$ were first-generation and $53 \%(n=829)$ were females.

At the end of 2007, 1,411 individuals (90.2\%) were alive. Of the 154 (9.8\%) deaths recorded during the study (with known date and cause of death), 74 (48.1\%) were due to cardiovascular diseases, followed by different types of cancer (21.4\%).

All-cause mortality rate was 10.68 /thousand person-years (95\%CI: 9.12-12.51/thousand person-years). Table 1 shows the absolute figures and percentages for the demographic, metabolic, lifestyle, and anthropometric variables (at study baseline) according to vital status at the end of the study, in addition to the mortality rate ratio. Gender (male), age ( $\geq 60$ years), generation (first), working status (no), years of schooling in Brazil 
Table 1

Number, percentage of individuals, and mortality rate ratios (MRR, thousand person-years), point rates, and $95 \%$ confidence intervals ( $95 \% \mathrm{CI}$ ) for baseline demographic, metabolic, lifestyle, and anthropometric variables according to vital status at the end of the study (alive or all-cause or cardiovascular mortality). Bauru, São Paulo State, Brazil, 2007.

\begin{tabular}{|c|c|c|c|c|c|c|c|c|}
\hline \multirow[t]{2}{*}{ Variable } & \multicolumn{2}{|c|}{ Alive $(n=1,411)$} & \multicolumn{3}{|c|}{ All-cause mortality $(n=154)$} & \multicolumn{3}{|c|}{ Cardiovascular mortality $(n=74)$} \\
\hline & $\mathrm{n}$ & $\%$ & $\mathbf{n}$ & $\%$ & MRR $(95 \% \mathrm{Cl})$ & $\mathbf{n}$ & $\%$ & MRR $(95 \% \mathrm{Cl})$ \\
\hline \multicolumn{9}{|l|}{ Gender } \\
\hline Female & 771 & 54.6 & 58 & 37.7 & 1.00 & 27 & 36.5 & 1.00 \\
\hline Male & 640 & 45.5 & 96 & 62.3 & $1.93(1.38-2.72)$ & 47 & 63.5 & $2.06(1.26-3.44)$ \\
\hline \multicolumn{9}{|l|}{ Age (year) } \\
\hline$<60$ & 918 & 65.1 & 42 & 27.3 & 1.00 & 22 & 29.7 & 1.00 \\
\hline$\geq 60$ & 493 & 34.9 & 112 & 72.7 & $4.23(2.94-6.18)$ & 52 & 70.3 & $3.93(2.34-6.79)$ \\
\hline \multicolumn{9}{|l|}{ Generation } \\
\hline First & 282 & 20.1 & 72 & 46.8 & 1.00 & 33 & 44.6 & 1.00 \\
\hline Second & 1,118 & 79.9 & 82 & 53.2 & $0.38(0.28-0.53)$ & 41 & 55.4 & $0.40(0.25-0.65)$ \\
\hline \multicolumn{9}{|l|}{ Smoking } \\
\hline No & 879 & 69.5 & 69 & 60.5 & 1.00 & 33 & 61.1 & 1.00 \\
\hline Yes & 386 & 30.5 & 45 & 39.5 & $1.53(1.03-2.26)$ & 21 & 38.9 & $1.51(0.83-2.69)$ \\
\hline \multicolumn{9}{|l|}{ Alcohol consumption } \\
\hline No & 887 & 65.3 & 86 & 67.2 & 1.00 & 43 & 71.7 & 1.00 \\
\hline Yes & 472 & 34.7 & 42 & 32.8 & $0.99(0.67-1.45)$ & 17 & 28.3 & $0.81(0.43-1.45)$ \\
\hline \multicolumn{9}{|l|}{ Working status } \\
\hline No & 636 & 45.3 & 105 & 68.2 & 1.00 & 51 & 68.9 & 1.00 \\
\hline Yes & 769 & 54.7 & 49 & 31.8 & $0.40(0.28-0.57)$ & 23 & 31.1 & $0.38(0.22-0.63)$ \\
\hline \multicolumn{9}{|l|}{ Physical activity } \\
\hline Sedentary/Light & 1,029 & 73.6 & 117 & 76.5 & 1.00 & 53 & 72.6 & 1.00 \\
\hline Active & 369 & 26.4 & 36 & 23.5 & $0.97(0.65-1.42)$ & 20 & 27.4 & $1.19(0.67-2.03)$ \\
\hline \multicolumn{9}{|l|}{ Marital status } \\
\hline Single/Widowed/Divorced & 306 & 21.8 & 31 & 20.1 & 1.00 & 15 & 20.3 & 1.00 \\
\hline Married & 1,098 & 78.2 & 123 & 79.9 & $1.07(0.71-1.63)$ & 59 & 79.7 & $1.06(0.59-2.01)$ \\
\hline \multicolumn{9}{|l|}{ Schooling in Brazil (years) } \\
\hline$\leq 4$ & 589 & 50.0 & 94 & 64.0 & 1.00 & 46 & 66.7 & 1.00 \\
\hline$>4$ & 589 & 50.0 & 52 & 36.0 & $0.58(0.40-0.82)$ & 22 & 33.3 & $0.51(0.29-0.86)$ \\
\hline \multicolumn{9}{|l|}{$\mathrm{BMI}\left(\mathrm{kg} / \mathrm{m}^{2}\right)$} \\
\hline$\leq 24.9$ & 769 & 55.1 & 83 & 55.3 & 1.00 & 44 & 60.3 & 1.00 \\
\hline $25-29.9$ & 506 & 36.2 & 53 & 35.3 & $0.90(0.51-1.59)$ & 21 & 28.8 & $1.33(0.79-2.23)$ \\
\hline$\geq 30$ & 122 & 8.7 & 14 & 9.4 & $0.90(0.50-1.62)$ & 8 & 10.9 & $1.61(0.71-3.63)$ \\
\hline \multicolumn{9}{|l|}{ Abdominal obesity (WC) } \\
\hline$<80 \mathrm{~cm}(\mathrm{~F})_{i}<90 \mathrm{~cm}(\mathrm{M})$ & 747 & 52.9 & 82 & 53.3 & 1.00 & 41 & 55.4 & 1.00 \\
\hline$\geq 80 \mathrm{~cm}(\mathrm{~F}) ; \geq 90 \mathrm{~cm}(\mathrm{M})$ & 664 & 47.1 & 72 & 46.7 & $0.94(0.67-1.31)$ & 33 & 44.6 & $0.86(0.53-1.39)$ \\
\hline \multicolumn{9}{|c|}{ Abdominal obesity (waist/hip ratio) } \\
\hline$<0.85(\mathrm{~F})_{i}<0.95(\mathrm{M})$ & 792 & 56.1 & 66 & 42.9 & 1.00 & 27 & 36.5 & 1.00 \\
\hline$\geq 0.85(\mathrm{~F}) ; \geq 0.95(\mathrm{M})$ & 619 & 43.9 & 88 & 57.1 & $1.35(0.97-1.88)$ & 47 & 63.5 & $2.74(1.06-2.91)$ \\
\hline \multicolumn{9}{|c|}{ Abdominal obesity (waist/height ratio) } \\
\hline$<0.50$ & 376 & 26.7 & 27 & 17.5 & 1.00 & 11 & 14.9 & 1.00 \\
\hline$\geq 0.50$ & 1,035 & 73.3 & 127 & 82.5 & $1.54(1.01-2.45)$ & 63 & 85.1 & $1.85(0.97-3.89)$ \\
\hline \multicolumn{9}{|l|}{ Glucose tolerance } \\
\hline Normal & 392 & 27.8 & 41 & 26.8 & 1.00 & 20 & 27.0 & 1.00 \\
\hline IFG & 361 & 25.6 & 15 & 9.8 & $0.63(0.40-1.01)$ & 8 & 10.8 & $1.32(0.58-3.00)$ \\
\hline IGT & 269 & 19.1 & 32 & 20.9 & $0.44(0.24-0.82)$ & 11 & 14.9 & $1.50(0.60-3.73)$ \\
\hline Diabetes & 389 & 27.5 & 65 & 42.5 & $1.41(0.92-2.15)$ & 35 & 47.3 & $3.29(1.53-7.10)$ \\
\hline
\end{tabular}

(continues) 


\begin{tabular}{|c|c|c|c|c|c|c|c|c|}
\hline \multirow[t]{2}{*}{ Variable } & \multicolumn{2}{|c|}{ Alive $(n=1,411)$} & \multicolumn{3}{|c|}{ All-cause mortality $(n=154)$} & \multicolumn{3}{|c|}{ Cardiovascular mortality $(n=74)$} \\
\hline & n & $\%$ & $\mathrm{n}$ & $\%$ & MRR $(95 \% \mathrm{Cl})$ & $\mathrm{n}$ & $\%$ & MRR (95\%Cl) \\
\hline \multicolumn{9}{|c|}{ Arterial hypertension } \\
\hline No & 923 & 65.7 & 73 & 47.7 & 1.00 & 32 & 43.2 & 1.00 \\
\hline Yes & 483 & 34.3 & 80 & 52.3 & $2.10(1.51-2.92)$ & 42 & 56.8 & $2.55(1.57-4.17)$ \\
\hline \multicolumn{9}{|c|}{ Dyslipidemia * } \\
\hline No & 232 & 16.5 & 28 & 18.3 & 1.00 & 9 & 12.2 & 1.00 \\
\hline Yes & 1,177 & 82.5 & 125 & 81.7 & $0.92(0.60-1.43)$ & 65 & 87.8 & $1.47(0.73-3.36)$ \\
\hline
\end{tabular}

BMI: body mass index; F: female; IFG: impaired fasting glucose; IGT: impaired glucose tolerance; M: male; WC: waist circumference.

* Total cholesterol $>200 \mathrm{mg} / \mathrm{dL}$ or triglycerides $>150 \mathrm{mg} / \mathrm{dL}$ or $\mathrm{HDL}<40 \mathrm{mg} / \mathrm{dL}$ for men and $<50 \mathrm{mg} / \mathrm{dL}$ for women or LDL $>130 \mathrm{mg} / \mathrm{dL}$.

( $\leq 4$ years), and hypertension were risk factors for all-cause and cardiovascular mortality. Smoking (yes) and presence of abdominal obesity according to waist/height ratio were only risk factors for all-cause mortality, while glucose intolerance (IGT) was a protective factor. Abdominal obesity according to waist/hip ratio and diabetes were risk factors for cardiovascular mortality.

Of the 1,565 individuals included in the study, $47 \%$ showed baseline abdominal obesity according to WC, $45.2 \%$ based on waist/hip ratio, and $74.3 \%$ according to waist/height ratio. No statistically significant differences were observed between the percentage of individuals that died when comparing those with or without abdominal obesity according to WC (47.1\% versus $52.9 \%$ for all causes, $\mathrm{p}=0.990 ; 44.6 \%$ versus $55.4 \%$ for cardiovascular mortality, $\mathrm{p}=0.684$ ). According to classification by waist/hip ratio and waist/height ratio, there were more deaths among those with baseline abdominal obesity (waist/hip ratio: $57.5 \%$ versus $42.5 \%$ for all-cause mortality, $\mathrm{p}=0.001 ; 63.5 \%$ versus $36.5 \%$ for cardiovascular mortality, $\mathrm{p}=0.001$; waist $/$ height ratio: $82.9 \%$ versus $17.1 \%$ for all-cause mortality, $\mathrm{p}=0.012$; $85.1 \%$ versus $14.9 \%$ for cardiovascular mortality, $\mathrm{p}=0.026)$.

Table 2 shows the mean values and respective 95\%CI for baseline demographic, metabolic, lifestyle, and anthropometric variables according to vital status at the end of the study. Subjects that had died (from all causes or cardiovascular diseases), compared to those that were alive at the end of the study, showed higher mean age, more baseline abdominal obesity (according to WC, waist/hip ratio, or waist/height ratio), higher fasting and 2-hour blood glucose, higher SBP and DBP, and lower HDL.

Table 3 shows the mortality rate ratios obtained through Poisson multiple regression analysis. Presence of abdominal obesity according to WC or waist/height ratio (yes/no) was not associ- ated with the target outcomes, while this association remained statistically significant for waist/ hip ratio (especially for cardiovascular mortality), even after adjusting simultaneously for other variables. Meanwhile, gender (male), age $(\geq 60$ years), and hypertension were independent risk factors for all-cause and cardiovascular mortality, regardless of the respective anthropometric index. Absence of dyslipidemia was an independent protective factor against all-cause and cardiovascular mortality, regardless of the anthropometric index.

\section{Discussion}

Few epidemiological cohort studies in Brazil have investigated associations between abdominal obesity and morbidity and mortality from chronic non-communicable diseases, and such studies are non-existent among Japanese immigrants. The current study followed a cohort of individuals outside of their country of origin for 14 years, which allowed evaluating the impact of environmental variables on mortality. In addition, the high proportion of subjects with complete follow-up in the mortality study (>90\%) reinforces the results presented here. This study is particularly relevant to the extent that it focuses on a theme of growing interest in international research in recent decades.

Most of the published studies on associations between obesity and mortality in population groups have only focused on the role of BMI $9,25,26,27$. However, it is known that lean individuals can show increased risk of cardiovascular diseases and other metabolic and inflammatory disorders if they present accumulated fat in the abdominal region 28 .

The mean baseline WC, waist/hip ratio, and waist/height ratio for Japanese-Brazilians were generally statistically higher (for waist/hip ra- 
Mean values and $95 \%$ confidence intervals $(95 \% \mathrm{Cl})$ for baseline demographic, metabolic, lifestyle, and anthropometric variables according to vital status at the end of the study (alive, all-cause mortality, cardiovascular mortality). Bauru, São Paulo State, Brazil, 2007.

\begin{tabular}{|c|c|c|c|c|c|c|c|c|}
\hline \multirow[t]{2}{*}{ Variable } & \multicolumn{2}{|c|}{ Alive $(n=1,411)$} & \multicolumn{3}{|c|}{ All-cause mortality $(n=154)$} & \multicolumn{3}{|c|}{ Cardiovascular mortality $(n=74)$} \\
\hline & Mean & $95 \% \mathrm{Cl}$ & Mean & $95 \% \mathrm{Cl}$ & $\mathrm{p}$-value $* . \star \star$ & Mean & $95 \% \mathrm{Cl}$ & $\mathrm{p}$-value $* . * \star \star$ \\
\hline Age (years) & 54.6 & $54.0-55.2$ & 65.1 & $63.5-66.8$ & $<0.001$ & 64.3 & $61.8-66.8$ & $<0.001$ \\
\hline Weight (kg) & 61.0 & $60.4-61.6$ & 59.9 & $57.9-61.8$ & 0.127 & 59.8 & $56.9-62.7$ & 0.193 \\
\hline Height (m) & 1.57 & $1.56-1.57$ & 1.56 & $1.55-1.57$ & 0.207 & 1.56 & $1.54-1.58$ & 0.256 \\
\hline Body mass index $\left(\mathrm{kg} / \mathrm{m}^{2}\right)$ & 24.8 & $24.6-25.1$ & 24.5 & $23.8-25.1$ & 0.160 & 24.6 & $23.7-25.5$ & 0.702 \\
\hline Waist circumference $(\mathrm{cm})$ & 84.4 & $83.8-84.9$ & 86.7 & $85.0-88.4$ & $<0.010$ & 86.5 & $84.3-88.7$ & $<0.050$ \\
\hline Waist/hip ratio & 0.88 & $0.88-0.89$ & 0.93 & $0.92-0.94$ & $<0.001$ & 0.94 & $0.92-0.95$ & $<0.001$ \\
\hline Waist/height ratio & 0.54 & $0.53-0.54$ & 0.56 & $0.55-0.57$ & $<0.010$ & 0.56 & $0.54-0.57$ & $<0.050$ \\
\hline Systolic blood pressure (mmHg) & 129.3 & $128.1-130.5$ & 147.6 & $\begin{array}{c}135.7- \\
159.4\end{array}$ & $<0.001$ & 157.0 & $133.1-180.9$ & $<0.001$ \\
\hline Diastolic blood pressure $(\mathrm{mmHg})$ & 79.0 & $78.2-79.8$ & 86.2 & $74.0-98.4$ & $<0.010$ & 95.3 & $70.1-120.5$ & $<0.001$ \\
\hline Fasting glucose (mg/dL) & 116.3 & $114.5-118.1$ & 123.8 & $\begin{array}{l}115.8- \\
131.8\end{array}$ & $<0.010$ & 128.5 & $115.4-141.6$ & $<0.010$ \\
\hline 2-hour glucose (mg/dL) & 150.3 & $146.5-154.1$ & 172.1 & $\begin{array}{c}158.5- \\
185.8\end{array}$ & $<0.001$ & 179.7 & $157.7-201.7$ & $<0.001$ \\
\hline Total cholesterol (mg/dL) & 214.1 & $211.8-216.3$ & 210.9 & $\begin{array}{c}203.0- \\
218.8\end{array}$ & 0.197 & 216.8 & $205.0-228.5$ & 0.298 \\
\hline HDL cholesterol (mg/dL) & 47.4 & $46.8-48.0$ & 44.5 & $42.6-46.5$ & $<0.010$ & 45.2 & $42.2-48.3$ & 0.047 \\
\hline LDL cholesterol (mg/dL) & 134.4 & $132.4-136.4$ & 129.9 & $\begin{array}{l}123.4- \\
136.4\end{array}$ & 0.086 & 130.9 & $120.7-141.0$ & 0.220 \\
\hline Triglycerides (mg/dL) & 206.3 & $197.5-215.2$ & 200.1 & $\begin{array}{l}171.1- \\
229.2\end{array}$ & 0.335 & 232.3 & $176.8-287.9$ & 0.106 \\
\hline
\end{tabular}

* Student t test;

** All-cause mortality versus alive;

*** Cardiovascular mortality versus alive.

tio and waist/height ratio) among individuals that died as compared to those that were alive at the end of the study. The prevalence rates for abdominal obesity according to WC, waist/hip ratio, and waist/height ratio were $47.1 \%, 45.3 \%$, and $74.4 \%$, respectively. This situation shows that although the group was not obese on average (mean BMI $24.4 \mathrm{~kg} / \mathrm{m}^{2}$ ), the high prevalence of abdominal obesity contributes to metabolic alterations in this community ${ }^{6}$. However, in order to compare this study's findings with those of other researchers, it is necessary to take into account the cutoff points, gender, and ethnicity, among other factors.

In the current study, only waist/hip ratio remained associated with cardiovascular mortality after adjusting for other variables such as gender, age, and hypertension. The use of waist/hip ratio alone requires caution, since interpretation of the results has to take the measurement of two variables into account: waist and hips 5,9.
Various researchers defend the use of waist/ hip ratio as the best measure for identifying presence of abdominal obesity. According to such authors, besides being associated with insulin resistance, glucose intolerance, and increased cardiovascular risk, waist/hip ratio is a good predictor of the occurrence of coronary artery disease and correlates well with the amount of intra-abdominal adipose tissue 7,29,30,31,32,33.

According to the current study, JapaneseBrazilians of both sexes with elevated waist/hip ratio (men $\geq 0.95$ and women $\geq 0.80$ ) had three times greater odds of dying from cardiovascular diseases. This result corroborates the findings of another study, in which individuals with elevated waist/hip ratio had a twofold risk of developing cardiovascular diseases; when a cutoff of 0.88 was used, the risk increased to threefold 34 .

Of the deaths recorded in this study, $48.1 \%$ were due to cardiovascular diseases, confirming the data showing that these are the most frequent 
Mortality rate ratios (MRR), point rates, and 95\% confidence intervals ( $95 \% \mathrm{Cl}$ ) obtained by Poisson multiple regression for presence of abdominal obesity (waist circumference - WC, waist/hip ratio, and waist/height ratio) and demographic, metabolic, lifestyle, and anthropometric variables. Bauru, São Paulo State, Brazil, 2007.

\begin{tabular}{|c|c|c|}
\hline Independent variable & $\begin{array}{l}\text { All-cause mortality } \\
\text { MRR }(95 \% \mathrm{Cl})\end{array}$ & $\begin{array}{c}\text { Cardiovascular mortality } \\
\text { MRR }(95 \% \mathrm{Cl})\end{array}$ \\
\hline \multicolumn{3}{|c|}{ Abdominal obesity according to WC (yes/no) } \\
\hline Model 1 & $1.13(0.81-1.56)$ & $1.04(0.65-1.66)$ \\
\hline Model 2 & $1.20(0.85-1.68)$ & $1.13(0.6-1.84)$ \\
\hline Model 3 & $1.32(0.86-2.02)$ & $1.46(0.76-2.80)$ \\
\hline Model 4 & $1.14(0.65-1.99)$ & $1.53(0.67-3.52)$ \\
\hline \multicolumn{3}{|c|}{ Abdominal obesity according to waist/hip ratio (yes/no) } \\
\hline Model 1 & $1.53(1.10-2.12)$ & $2.06(1.27-3.34)$ \\
\hline Model 2 & $1.43(1.02-2.00)$ & $1.90(1.15-3.16)$ \\
\hline Model 3 & $1.32(0.86-2.02)$ & $2.50(1.26-4.96)$ \\
\hline Model 4 & $1.23(0.77-1.98)$ & $2.81(1.32-6.00)$ \\
\hline \multicolumn{3}{|c|}{ Abdominal obesity according to waist/height ratio (yes/no) } \\
\hline Model 1 & $1.36(0.89-2.08)$ & $1.64(0.86-3.12)$ \\
\hline Model 2 & $1.36(0.88-2.11)$ & $1.77(0.88-3.57)$ \\
\hline Model 3 & $1.57(0.87-2.83)$ & $2.27(0.80-6.42)$ \\
\hline Model 4 & $2.27(0.80-6.42)$ & $2.30(0.76-6.97)$ \\
\hline
\end{tabular}

Model 1: adjusted only for gender and age; model 2: variables from model 1 plus generation, working status, schooling, and marital status; model 3: variables included in model 2 plus physical activity, alcohol consumption, and smoking; and (d) model 4: variables included in model 3 plus body mass index (BMI), glucose tolerance, dyslipidemia, and hypertension.

diseases in the Brazilian population. Despite the downward trend in cardiovascular mortality in Brazil and in the world, some projections indicate an increase in its relative importance in low- and middle-income countries. Greater longevity and a possible rise in the incidence of cardiovascular diseases due to the adoption of lifestyles with greater exposure to risk factors are considered the principal reasons for this increase 35 .

Diseases of the circulatory system (cerebrovascular and ischemic heart diseases) contribute significantly as a causal group for mortality in all the geographic regions of Brazil. According to the Ministry of Health, the Southeast has the highest mortality rate due to diseases of the circulatory system (2.07 deaths per 1,000 inhabitants), while the mean for Brazil as a whole is 1.69 per 1,000. This study found 10.68 deaths from all causes per 1,000 inhabitants and 5.28 per 1,000 due to cardiovascular diseases. Cardiovascular diseases represent nearly one-third of all deaths and $65 \%$ of all deaths in the 30-69-year age bracket, affecting the adult population in its most productive phase (Rede Interagencial de Informações para a Saúde. Indicadores de Mortalidade. http://tab net.datasus.gov.br/cgi/deftohtm.exe?idb2009/ c04.def).
These data corroborate other studies in the Japanese-Brazilian community in Bauru, showing that this population is at high risk for diabetes, dyslipidemia, hypertension, cardiovascular disease, and metabolic syndrome 13,14,15,26.

In this study, as expected, individuals that died from all causes or from cardiovascular diseases displayed a worse metabolic and anthropometric profile. In particular, hypertension, dyslipidemia, male gender, and age $\geq 60$ years were independent factors for all-cause and cardiovascular mortality. Such findings are consistent with the majority of prospective studies in the literature 25,27 . The findings also agree with the study among Japanese-Brazilians that participated in the first phase of the JBDSG project ${ }^{36}$.

Some limitations to the study should be considered: (1) one cannot rule out the possibility of errors in the anthropometric measurements; at any rate, the choice of a standardized methodology for collecting this information probably minimized the occurrence of this bias; (2) certain individual characteristics are known to change over time (e.g. weight and BMI variation, sedentary lifestyle, diet, and smoking), and when ignored these changes can alter the research findings; however, it was not possible to evaluate this issue in the 
current study, since not all the information needed for this purpose was available; and (3) although there were some losses to follow-up, they represented less than $10 \%$ of the sample and their impact on the results can thus be considered minimal.

\section{Conclusion}

Based on the findings, one can conclude that the prevalence of abdominal obesity among Japanese-Brazilians was high, and that high values for waist/hip ratio served as a risk factor for cardiovascular mortality, independently of gender, age, and presence of hypertension or dyslipidemia, thus suggesting that for these individuals, waist/ hip ratio is the best predictor of mortality.

\section{Resumo}

O objetivo foi verificar qual medida antropométrica de obesidade abdominal melhor prediz mortalidade geral e por doenças cardiovasculares entre nipo-brasileiros. Foram seguidos, por 14 anos, 1.581 sujeitos. Coletaram-se dados sociodemográficos, de estilo de vida, metabólicos e antropométricos. Considerou-se vivo ou óbito ao final do estudo como variável dependente e a presença de obesidade abdominal por diferentes medidas na linha de base como variável independente. Estimou-se o coeficiente de mortalidade e se usou o modelo de Poisson para obtenção das razões entre eles e a obesidade abdominal, ajustados simultaneamente às demais variáveis. O coeficiente de mortalidade foi de 10,68/mil pessoas-ano. O gênero masculino, a ida$d e \geq 60$ anos e ter hipertensão arterial foram fatores de risco independentes para mortalidade. Os resultados indicaram que entre nipo-brasileiros a prevalência de obesidade abdominal foi elevada e que a razão cintura quadril foi a medida que apresentou maior capacidade de predizer a mortalidade, especialmente cardiovascular, entre tais indivíduos.

Antropometria; Obesidade Abdominal; Mortalidade

\section{Contributors}

M. R. Bevilacqua and S. G. A. Gimeno were responsible for the data collection and analysis, interpretation of the results, and preparation of the manuscript.

\section{Acknowledgments}

The São Paulo State Research Foundation (FAPESP, grants 98/04178-7 and 2005/59178-7) and the Brazilian National Research Council (CNPq, grant505845/2004-0) supported the development of studies by the JapaneseBrazilian Diabetes Study Group. 


\section{References}

1. Monteiro CA. Epidemiologia da obesidade. In: Halpern A, Matos AFG, Suplicy HL, Mancini MC, Zanella MT, organizadores. Obesidade. São Paulo: Lemos Editorial; 1998. p. 15-30.

2. Ogden CL, Carroll MD, Curtin LR, McDowell MA, Tabak CJ, Flegal KM. Prevalence of overweight and obesity in the United States, 1999-2004. JAMA 2006; 295:1549-55.

3. Health Promotion and Nutrition Research Association. The National Nutrition Survey in Japan, 2000. Tokyo: Daiichi Publishing Co.; 2002.

4. Instituto Brasileiro de Geografia e Estatística. Pesquisa de Orçamento Familiar (2008-2009): antropometria e estado nutricional de crianças, adolescentes e adultos no Brasil. Rio de Janeiro: Instituto Brasileiro de Geografia e Estatística; 2010.

5. Després JP. Health consequences of visceral obesity. Ann Med 2001; 33:534-41.

6. Lerario DDG, Gimeno SG, Franco LJ, Iunes M, Ferreira SRG. Excesso de peso e gordura abdominal para a síndrome metabólica em nipo-brasileiros. Rev Saúde Pública 2002; 36:4-11.

7. Larsson B, Svärdsudd K, Welin L, Wilhelmsen L, Björntorp P, Tibblin G. Abdominal adipose tissue distribution, obesity, and risk of cardiovascular disease and death: 13 year follow up of participants in the study of men born in 1913. Br Med J (Clin Res Ed) 1984; 288:1401-4.

8. Welborn TA, Dhaliwal SS. Preferred clinical measures of central obesity for predicting mortality. Eur J Clin Nutr 2007; 61:1373-9.

9. Pischon T, Boeing H, Hoffmann K, Bergmann M, Schulze MB, Overvad K, et al. General and abdominal adiposity and risk of death in Europe. N Engl J Med 2008; 359:2105-20.

10. Hsieh SD, Yoshinaga H. Abdominal fat distribution and coronary heart disease risk factors in men waist/height ratio as a simple and useful predictor. Int J Obes Relat Metab Disord 1995; 19:585-9.

11. Hsieh SD, Yoshinaga H. Waist/height ratio as a simple and useful predictor of coronary heart disease risk factors in women. Int J Med 1995; 34:1147-52.

12. Hsieh SD, Yoshinaga H, Muto T. Waist-to-height ratio, a simple and practical index for assessing central fat distribution and metabolic risk in Japanese men and women. Int J Obes Relat Metab Disord 2003; 27:610-6.

13. Franco LJ. Diabetes in Japanese-Brazilians: influence of the acculturation process. Diabetes Res Clin Pract 1996; 34 Suppl:S51-7.

14. Ferreira SRG, Iunes M, Franco LJ, Iochida LC, Hirai A, Vivolo MA. Disturbances of glucose and lipid metabolism in first and second generation Japanese-Brazilians. Japanese-Brazilian Diabetes Study Group. Diabetes Res Clin Pract 1996; 34 Suppl: S59-63.

15. Gimeno SGA, Ferreira SRG, Franco LJ, Hirai AT, Matsumura L, Moisés RS. Prevalence and 7-year incidence of type II diabetes mellitus in a Japanese-Brazilian population: an alarming public health problem. Diabetologia 2002; 45:1635-8.
16. Souza RKT, Gotlieb SLD. Mortalidade em migrantes japoneses residentes no Paraná, Brasil. Rev Saúde Pública 1999; 33:262-72.

17. Damião R, Sartorelli DS, Hirai A, Massimino F, Poletto J, Bevilacqua MR, et al. Nutritional intervention programme among a Japanese-Brazilian community: procedures and results according to gender. Public Health Nutr 2010; 13:1453-61.

18. World Health Organization. Obesity: preventing and managing the global epidemic. Report of a WHO Consultation on Obesity. Geneva: World Health Organization; 1998.

19. Inoue S, Zimmet P. The Asia-Pacific perspective: redefining obesity and its treatment. Melbourne: World Health Organization Western Pacific Region/Health Communications Australia Pty Limited; 2000 .

20. International Diabetes Federation. The IDF consensus worldwide definition of the metabolic syndrome. Brussels: International Diabetes Federation; 2006.

21. Bray GA, Bouchard C, James WPT. Handbook of obesity. New York: Marcel Dekker; 1998.

22. Chobanian AV, Bakris GL, Black HR, Cushman WC, Green LA, Izzo Jr. JL, et al. Seventh report of the Joint National Committee on Prevention, Detection, Evaluation, and Treatment of High Blood Pressure. Hypertension 2003; 42:1206-52.

23. Alberti KGMM, Zimmet PZ. Definition, diagnosis and classification of diabetes mellitus and its complications. Geneva: World Health Organization; 1999.

24. Expert Panel on Detection, Evaluation, and Treatment of High Blood Cholesterol in Adults. Executive Summary of the Third Report of the National Cholesterol Education Program (NCEP) Expert Panel on Detection, Evaluation, and Treatment of High Blood Cholesterol in Adults (Adult Treatment Panel III). JAMA 2001; 285:2486-97

25. Flegal KM, Graubard BI, Williamson DF, Gail MH. Excess deaths associated with underweight, overweight, and obesity. JAMA 2005; 293:1861-7.

26. Massimino FC, Gimeno SGA, Ferreira SRG; Japanese-Brazilian Diabetes Study Group. All-cause mortality among Japanese-Brazilians according to nutritional characteristics. Cad Saúde Pública 2007; 23:2145-56.

27. Prospective Studies Collaboration; Whitlock G, Lewington S, Sherliker P, Clarke R, Emberson J, et al. Body mass index and cause-specific mortality in 900,000 adults: collaborative analyses of 57 prospective studies. Lancet 2009; 373:1083-96.

28. Ruderman N, Chisholm D, Pi-Sunyer X, Schneider $\mathrm{S}$. The metabolically obese, normal-weight individual revisited. Diabetes 1998; 47:699-713.

29. Ashwell M, Cole TJ, Dixon AK. Obesity: new insight into the anthropometric classification of fat distribution shown by computed tomography. BMJ 1985; 290:1692-4. 
30. Sayeed MA, Mahtab H, Latif ZA, Khanam PA, Ahsan KA, Banu A, et al. Waist-to-height ratio is a better obesity index than body mass index and waistto-hip ratio for predicting diabetes, hypertension and lipidemia. Bangladesh Med Res Counc Bull 2003; 29:1-10

31. Lakka HM, Laaksonen DE, Lakka TA, Niskanen LK, Kumpusalo E, Tuomilehto J, et al. The metabolic syndrome and total and cardiovascular disease mortality in middle-aged men. JAMA 2002; 288:2709-16.

32. Kragelund C, Omland T. A farewell to body mass index? Lancet 2005; 366:1589-91.

33. Björntorp P. Body fat distribution, insulin resistance, and metabolic diseases. Nutrition 1997; 13:795-803.
34. Rexrode KM, Carey VJ, Hennekens CH, Walters EE, Colditz GA, Stampfer MJ, et al. Abdominal adiposity and coronary heart disease in women. JAMA 1998; 280:1843-8.

35. Lenfant C. Can we prevent cardiovascular diseases in low- and middle-income countries? Bull World Health Organ 2001; 79:980-2.

36. Gimeno SG, Osiro K, Matsumura L, Massimino FC, Ferreira SR; Japanese-Brazilian Diabetes Study Group. Glucose intolerance and all-cause mortality in Japanese migrants. Diabetes Res Clin Pract 2005; 68:147-54.

Submitted on 15/Sep/2010

Final version resubmitted on 27/Apr/2011

Approved on 18/May/2011 